\title{
Refining the classification of knowledge transfer mechanisms for project-to-project knowledge sharing
}

\begin{tabular}{|c|c|}
\hline \multicolumn{2}{|c|}{$\begin{array}{l}\text { Authors: } \\
\text { Corro Van Waveren }^{1} \\
\text { Leon Oerlemans }^{2} \text { (D) } \\
\text { Tinus Pretorius }\end{array}$} \\
\hline \multicolumn{2}{|c|}{$\begin{array}{l}\text { Affiliations: } \\
\text { 'Department of Engineering } \\
\text { and Technology } \\
\text { Management, Graduate } \\
\text { School of Technology } \\
\text { Management, University of } \\
\text { Pretoria, South Africa }\end{array}$} \\
\hline \multicolumn{2}{|c|}{$\begin{array}{l}\text { Department of Organization } \\
\text { Studies, Faculty of Social } \\
\text { Sciences, Tilburg University, } \\
\text { the Netherlands }\end{array}$} \\
\hline \multicolumn{2}{|c|}{$\begin{array}{l}\text { Corresponding author: } \\
\text { Leon Oerlemans, } \\
\text { l.a.g.oerlemans@uvt.nl }\end{array}$} \\
\hline \multicolumn{2}{|c|}{$\begin{array}{l}\text { Received: } 04 \text { Aug. } 2016 \\
\text { Accepted: } 29 \text { May } 2017 \\
\text { Published: } 05 \text { Oct. } 2017\end{array}$} \\
\hline \multicolumn{2}{|c|}{$\begin{array}{l}\text { How to cite this article: } \\
\text { Van Waveren, C., Oerlemans, } \\
\text { L. \& Pretorius, T., 2017, } \\
\text { 'Refining the classification of } \\
\text { knowledge transfer } \\
\text { mechanisms for project-to- } \\
\text { project knowledge sharing', } \\
\text { South African Journal of } \\
\text { Economic and Management } \\
\text { Sciences 20(1), a1642. } \\
\text { https://doi.org/10.4102/ } \\
\text { sajems.v20i1.1642 }\end{array}$} \\
\hline \multicolumn{2}{|c|}{$\begin{array}{l}\text { Copyright: } \\
\text { (c) 2017. The Authors. } \\
\text { Licensee: AOSIS. This } \\
\text { is licensed under the } \\
\text { Creative Commons } \\
\text { Attribution License. }\end{array}$} \\
\hline \multicolumn{2}{|l|}{ Read online: } \\
\hline 品铝回 & $\begin{array}{l}\text { Scan this QR } \\
\text { code with your } \\
\text { smart phone or } \\
\text { mobile device } \\
\text { to read online. }\end{array}$ \\
\hline
\end{tabular}

Authors:

Corro Van Waveren

Tinus Pretorius ${ }^{1}$

Affiliations:

Management, University of

${ }^{2}$ Department of Organization Studies, Faculty of Social

Sciences, Tilburg University,

Netherlands

Leon Oerlemans,

Dates:

Received: 04 Aug. 2016

Accepted: 29 May 2017

blished: 05 Oct. 2017

ow to cite this article:

L. \& Pretorius, T., 2017,

'Refining the classification of

project knowledge sharing',

South African Journal of

Economic and Management

Sciences 20(1) a1642.

https://doi.org/10.4102/

ms.v20i1.1642

Licensee: AOSIS. This work

is licensed under the

Creative Commons

Attribution License.

mobile device

to read onlin
Background: The complex, unique and temporary nature of projects makes project-to-project knowledge transfer challenging and has attracted attention from both practitioners and academic scholars. This challenging nature of project-to-project knowledge transfer led to the proliferation of a host of tools and instruments (so-called knowledge transfer mechanisms) in which little structure can be discovered making selection by (project) managers a difficult task.

Aim: This article aims to deal with this unstructured proliferation of knowledge transfer mechanisms by empirically categorising these transfer mechanisms, thereby reducing the number of mechanisms to groups that share a common characteristic.

Setting: The study takes stock of the wide range of knowledge transfer mechanisms available and analyses them in terms of specific characteristics (e.g. explicitness or reach).

Methods: A multi-method approach is used in which a multi-level latent class analysis is applied on data collected via an expert panel.

Results: Five categories of transfer mechanisms could be empirically established where these mechanisms showed common characteristics.

Conclusion: The taxonomy developed will allow organisations and project managers to more efficiently select appropriate transfer mechanisms for use in project-to-project knowledge transfer.

\section{Introduction}

An increasing number of organisations use temporary organisations, such as projects and task forces, to carry out their economic and societal activities (Bakker et al. 2011; Whittington et al. 1999). In instances where a major part or all of these activities of an organisation are conducted in the form of projects, these organisations are referred to as project-based organisations. This organisational form is increasingly present in a variety of industries. Examples of relevant industries are engineering (Winch 2014), advertising (Grabher 2004), construction (Eriksson 2013), shipbuilding (Levering et al. 2013) and television (Manning \& Sydow 2007). Several scholars (Godenhjelm, Lundin \& Sjöblom 2015; Packendorff \& Lindgren 2014) even argue that this emergence of a projectoriented way of organising activities is part of a broader societal trend, which they label as 'projectification'. These authors distinguish a so-called narrow and broad definition of the concept. The narrow conception regards the development towards the use of projects for handling complex tasks and creative change in modern organisations. The broad conceptualisation of 'projectification' concerns cultural and societal processes whereby projects and project-like circumstances are embedded in the activities of individuals, the organising of all sorts of work and society at large. This wide proliferation of project-based working and thinking implies that the research problem addressed in and insights provided by this article not only have value for the business world, but can find a wide application outside this world. This stresses the relevance of this study.

In this projectised and technological world, knowledge is a vital resource to any organisation. This is even more the case in project-based organisations (Love, Edum-Fotwe \& Irani 2003) because in order for project-based organisations to deliver new products and expanding new markets, relevant parts of the knowledge and information in the source organisation and experiences of employees and team members need to be made available to subsequent projects (Van Donk \& Riezebos 2005). In a project-based organisation, 'the knowledge, capabilities, and resources of the firm are built up through the execution of major projects' (Hobday 2000).

The growing importance of knowledge for the organisational outcomes is also reflected in the academic literature by the emergence of the knowledge-based perspective of the firm 
(Grant 1996). This perspective builds upon and extends the resource-based theory of the firm initially promoted by Penrose (1959) and expanded by others (Barney 2001; Kraaijenbrink, Spender \& Groen 2010). The knowledge-based perspective argues that the functions performed by tangible resources depend on how they are combined and applied, which is in turn a function of the firm's knowledge. This knowledge is embedded in and transferred by multiple entities including organisation culture, routines and norms, systems and documents, as well as organisational teams, groups and individuals. As knowledge-based resources are usually difficult, costly to imitate and socially complex, the knowledge-based view of the firm maintains that these resources may generate long-term sustainable competitive advantage. It should be noted, however, that having knowledge at any given time is not decisive for creating or maintaining a competitive advantage, but rather the firm's ability to effectively and efficiently use this knowledge to create new knowledge and implement it so it can create sustainable competitive advantage from its knowledgebased resources.

Put differently and applied to project-based organisations, the importance of knowledge and its application to create sustainable competitive advantage puts project-based learning at the centre of attention. Project-based learning comprises of the creation and acquisition of knowledge within projects, and the codification and transfer of this knowledge across project boundaries, for example, to subsequent projects (Bakker et al. 2011). In project-based organisations, this type of learning is regarded as a key performance driver as prior projects offer potentially valuable experiences that can be applied in similar projects in the future or generate new knowledge about the organisation's technology and market base that could lead to new business offerings (Bartsch, Ebers \& Maurer 2013).

Project-based learning ${ }^{1}$ is far from being unproblematic. In fact, the literature suggests that projects experience a socalled learning paradox (Bakker et al. 2011). More specifically, these authors (Bakker et al. 2011) maintain that:

on the one hand, through their transience and inter-disciplinary nature, project ventures are likely to be very suitable for creating knowledge in the context of its application. On the other hand, however, the temporary nature of projects by the same token seems to inhibit the sedimentation of knowledge, because when the project dissolves and participants move on, the created knowledge is likely to disperse. (p. 494)

The problem caused by the learning paradox has been recognised in both the academic and the practitioner literature, and a wide variety of approaches has been developed to deal with it that can be united under the general heading of knowledge management (Alavi \& Leidner 2001). Knowledge management refers to identifying and leveraging the collective knowledge in an organisation to help the organisation compete. It is seen as a process involving various activities. At a minimum, scholars distinguish four basic processes of creating, storing and/or retrieving, transferring and applying knowledge (Heisig 2009).

In this article, the focus is on project-to-project knowledge transfer and the mechanisms and tools proposed to make this transfer happen. The matter is that in the literature, there has been a substantive proliferation of knowledge transfer mechanisms and tools. As a consequence, a large number of transfer mechanisms are available, but a clear, comprehensive overview is lacking. This indistinctness makes the selection of knowledge transfer mechanism difficult for project and knowledge managers. Therefore, some order or structuring of transfer mechanisms might be useful.

The aim of this study is, therefore, to identify a wider range of knowledge transfer mechanism clusters through which transfer mechanisms can be grouped together according to a common purpose or application. This will be accomplished by executing the following steps, which also form the outline of this article:

- to determine from the literature, which knowledge transfer mechanisms are available to transfer knowledge across projects;

- to determine from literature, a set of dimensions with which one can group the identified knowledge transfer mechanisms according to their capability in transferring knowledge with a certain characteristic;

- to empirically define knowledge transfer mechanism clusters that share similar characteristics.

To address this variety of steps, the study opted for a socalled mixed methods approach in which qualitative and quantitative methods are used. More specifically, a sequential mixed method design (Tashakkori \& Teddlie 1989) was chosen where a qualitative study (in our case literature reviews and expert panel) informs a quantitative study (in our case a multi-level latent class analysis). Such a design is regarded appropriate if a research is (partly) exploratory.

This study contributes to the literature in several ways. Firstly, it generates a literature-based, state-of-the-art and up-to-date overview of knowledge transfer mechanisms and tools that can be used in across project knowledge transfer activities. Secondly, it develops, on the basis of a consultation of a group of experts, a fine-grained typology or classification structure for knowledge transfer mechanisms, where these different transfer mechanisms can be used to transfer knowledge across projects.

At a more general level, it answers a call for more research as specified by Argote, McEvily and Reagans (2003) who conclude that one of the emerging themes in the field is that knowledge management outcomes are affected by the 'fit' or congruence between features of knowledge, of the interacting organisational units, and the features of the intra- or inter-organisational relationships between units. But before we can study the relationship between this fit 
and outcomes, a first step that has to be set is creating a typology of project-to-project, which is exactly what this article intends to do.

\section{Classifying knowledge transfer mechanisms and tools: Earlier research}

The problems and hurdles of across project knowledge transfer are acknowledged by many in the field and a large proliferation of transfer mechanisms or tools are identified by several studies (Boh \& Wong 2013; Jasimuddin 2007; Jasimuddin \& Zhang 2009; Ruuska \& Vartiainen 2005). However, with so many mechanisms available, a result is that there is little structure in grouping these tools that will allow organisations to be more efficient in the selection and use of transfer mechanisms and tools. Furthermore, this lack of structure hinders scholars wanting to study the effects of the use of these mechanisms and tools. Using typologies would be helpful for these purposes.

Over the years, researchers developed such typologies to classify objects into groups according to similar attributes or characteristics. The advantage of using typologies is their ability to focus on those specific attributes without necessarily providing an in-depth and separate analysis of each and every item that belongs to a category.

Using a comparative case study approach, Prencipe and Tell (2001) analysed the mechanisms adopted by projectbased organisations to determine how firms are able to learn from and across projects, therefore identifying the processes in project-based organisations which are involved in the management of knowledge, as well as the collective mechanisms used for developing knowledge that can be reused in other activities and projects. Based on the learning processes defined by Zollo and Winter (2002), Principe and Tell developed a matrix of different project-to-project learning mechanisms by combining an organisational reach dimension with elements of a knowledge life cycle dimension. From this matrix, Prencipe and Tell (2001) defined learning landscapes which refer to the collection or portfolio of learning mechanisms used by individual firms which reflects the multi-dimensional nature of a firm's approach to project-toproject learning. Dimensions used for categorising their learning landscapes included the learning process from experience accumulation to knowledge codification and levels of analysis from the individual level, project level to the organisation level.

Boh (2007) established a framework of knowledge transfer mechanisms for managing distributed knowledge and expertise in project-based organisations by identifying four quadrants. These quadrants categorise knowledge transfer mechanisms according to a personalisation (knowledge transferred from person-to-person) versus codification (knowledge transfer though documentation) knowledge transfer strategy as defined by Hansen, Nohria and Tierney
(1999) on the one axis, and a socialisation strategy in terms of individualised (informal) versus institutionalised (formal) on the other axis. From their study, companies could be given a recommendation on the type of knowledge transfer mechanism to be used for standardised tasks versus tasks that are more unique of nature, as well as mechanism to be used for organisations that are larger and geographically dispersed versus organisations that are small and collocated.

In a later study, Jasimuddin and Zhang (2009) categorised knowledge transfer mechanisms into two groups, namely, soft and hard transfer mechanisms. Soft transfer mechanisms mainly deal with tacit knowledge, low use of technology and are people focussed, while hard transfer mechanisms deal with explicit knowledge, and are technology focussed with people playing a very small role.

The studies discussed in the above have some characteristics in common. Firstly, they categorise knowledge transfer mechanisms and tools on the basis of two dimensions of knowledge only. For reasons of simplicity this is a feasible and understandable approach. However, knowledge transfer mechanisms and tools often are of a more complex nature. The implication is that more than two of their characteristics have to be taken into account to arrive at a more fine-grained categorisation. Secondly, the validation of the categorisations developed in these studies is done by conducting a limited number of case studies in a wide variety of sectors, in which the categorisation is based on decisions by researchers. A possible disadvantage of this approach could be that they are not fully equipped to make proper inferences in all cases. Thirdly, in the fast moving world of digital media, these research papers are relatively old and often not capturing the use of social media to the fullest extent, therefore not directly focussing on project-toproject knowledge transfer.

The topics addressed in this section logically ask for a number of steps and different research approaches to be conducted in this research project: (1) Make a state-of-the art overview of knowledge transfer mechanisms and tools (Identifying knowledge transfer mechanisms and tools section); (2) Distinguish additional dimensions of mechanisms and tools (Identifying knowledge transfer mechanism characteristics section); (3) Use experts to better qualify mechanisms and tools and maximise variation in the data (Valuing knowledge transfer mechanism characteristics section).

\section{Identifying knowledge transfer mechanisms and tools \\ Methodological approach for identifying knowledge mechanisms and tools}

To create an up-to-date and state-of-the art overview of knowledge transfer mechanisms and tools, a literature review was done using several databases, including Scopus, 
Web of Science, Science Direct and others. As the Scopus and Web of Science databases are seen as two of the most authoritative databases (Aghaei Chadegani et al. 2013), these two databases were mainly used. To gain an overview of the main concepts, several keywords and search terms were used and listed in Table 1.

More than 150 papers were identified and retrieved from the different databases. These papers were first briefly scanned in order to determine applicability to the topic. Suitable papers were imported into the ATLASti Qualitative Data Analysis software tool. Within ATLASti, each paper was coded according to the conceptual attributes that could be identified from the manuscript. These codes were later grouped and analysed to obtain a list of knowledge transfer mechanisms, as well as knowledge transfer capability characteristics of the mechanisms to be used as dimensions for analysis. The next two sections address the identified transfer mechanism, as well as knowledge transfer mechanism characteristics in more detail.

\section{Knowledge transfer mechanisms identified}

In the context of projects, knowledge transfer mechanisms can be defined as the formal and informal means of transmission for sharing, integrating, interpreting and applying know-what and know-how embedded in individuals and groups that will aid in the performance of project tasks (Boh 2007; Jasimuddin, Connell \& Klein 2014). From the literature including the work of various scholars (Brachos et al. 2007; Duffield \& Whitty 2015; Frank, Ribeiro \& Echeveste 2015; Jasimuddin et al. 2014; Jeon, Kim \& Koh 2011; Ortega 2001; Patriotta, Castellano \& Wright 2013; Prencipe \& Tell 2001; Sáenz, Aramburu \& Blanco 2012; vom Brocke \& Lippe 2015; Wickramasinghe \& Widyaratne 2012), a variety of transfer mechanisms were identified that are in principle applicable to project-to-project knowledge transfer. In the literature, some mechanisms were discussed in some detail, while others were only mentioned by name. From the selected papers, 73 mechanisms where initially identified and after carefully evaluating each mechanism's description, those mechanisms with a highly similar description were grouped together under a common name. This reduced the number of mechanisms to a total of 59 to be included in the study. The final list of the 59 tools and mechanism, including a brief description is provided in alphabetical order in Table 1-A1. The next section addresses the knowledge transfer mechanism characteristics in more detail.

TABLE 1: Keywords and search terms.

\begin{tabular}{ll}
\hline Keywords & Alternatives and derivatives \\
\hline Transfer mechanism & - Sharing mechanism, \\
& - Transfer tools, \\
- Sharing tools, \\
- Trssemination tools, \\
- Transfer methods, \\
- Transfer platforms, \\
- Knowledge transfer instruments. \\
- Transfer characteristics, \\
Mechanism classification & - Knowledge sharing characteristics, \\
& Sharing dimensions. \\
\hline
\end{tabular}

\section{Identifying knowledge transfer mechanism characteristics Methodological approach}

In the previous section, a total of 59 knowledge transfer mechanisms were identified. These mechanisms need to be described by a number of dimensions (more than two), which will enable a fine-grained categorisation. The knowledge transfer mechanisms, therefore, need to have a specific ability, fitness or quality that is necessary to facilitate knowledge transfer across projects. In order to find dimensions for knowledge transfer mechanisms, the original literature review also included a search on the characteristics of knowledge flow and the capability of transfer mechanisms to transfer knowledge of a specific knowledge characteristic. The literature review was able to identify a number of characteristic elements, namely, knowledge explicitness (Snider \& Nissen 2003), knowledge richness (Boh 2007), knowledge stickiness (Cummings \& Teng 2003), knowledge reach (Nissen 2007), knowledge flow time (Snider \& Nissen 2003) and timeliness (Cummings \& Teng 2003), knowledge formality (Boh \& Wong 2013; Patriotta et al. 2013) and knowledge distortion (Hansen 2002). As knowledge explicitness, richness and the stickiness characteristic element relate to each other these three are combined into a single element namely knowledge explicitness and together with the remaining four make up the five knowledge transfer mechanism characteristic dimension that will be used in this study and are discussed in the following sub-sections.

\section{Explicitness dimension}

Knowledge explicitness can be defined as how codified a particular piece of knowledge is if one would place this knowledge on a continuum scale. The two extremes of this continuum would be tacit knowledge on the one hand versus explicit knowledge on the other (Snider \& Nissen 2003). According to Nonaka (2007), new knowledge is often tacit and always starts within the individual. Tacit knowledge is personalised knowledge and consists partly of technical skills or so-called know-how, which is hard to write down, but can also consist of mental models, beliefs and perspectives that are so engraved that they can be taken for granted (Nonaka 2007). At the other end of the continuum explicit knowledge is found, which is formal and systematic and can be easily codified, communicated and shared. Typical examples include product specifications, operating procedures, instructions, scientific formula and computer programmes and databases (Nonaka 2007; Snider \& Nissen 2003). Hansen et al. (1999) maintained that firms can follow two knowledge management strategies, namely, a personalisation strategy (tacit knowledge closely tied to the individual that developed the knowledge) and a codification strategy (explicit knowledge codified and routinised and revolve around ICT-based technologies). Companies can, therefore, manage this knowledge in essentially the same way as part of either a knowledge 
personalisation strategy, or a knowledge codification (technology-based) strategy or even a combination thereof (Ambos \& Ambos 2009). For the purpose of this study, the explicitness dimension is categorised into three groupings as depicted in Table 2.

\section{Reach dimension}

Knowledge reach is defined as the extent to which knowledge is shared with others in and across organisation units, for example, team members, project, departments and organisations, as well as the number of people affected by the knowledge. Snider and Nissen (2003) and Nonaka (1994) define four organisation-based aggregations of people, namely the individual, the work group, the organisation and the inter-organisation aggregation. In a more recent metaanalysis on research publications on the topic of knowledge brokering in project management, Holzmann (2013) identified four organisational levels across in which knowledge can flow, namely, the team, the project, the organisational level and industry. By combining the different levels as defined by previous authors, this study defines knowledge reach on project-based organisations as aggregations of people across various types of organisational boundaries, namely the individual, the project team, organisational project teams and inter-organisational project teams. The reach dimension can be used for categorising knowledge transfer mechanisms in the sense that certain mechanisms are more suited to transfer knowledge from person-to-person, that is, coaching, while other mechanisms are more suited for transferring knowledge over larger distances and addressing more people, that is, training sessions.

For this study, knowledge reach is illustrated in the following reach levels, namely the individual, the project team, organisational project teams and inter-organisational project teams as described in Table 3.

TABLE 2: Explicitness dimension.

\begin{tabular}{lll}
\hline Dimension number & Choice & Description \\
\hline 1 & Mainly tacit & $\begin{array}{l}\text { The mechanism is capable to transfer } \\
\text { mainly tacit knowledge from sender to } \\
\text { receiver }\end{array}$ \\
\hline 3 & Mainly dualistic & $\begin{array}{l}\text { The mechanism is capable to transfer } \\
\text { both tacit and explicit knowledge from } \\
\text { sender to receiver }\end{array}$ \\
\hline
\end{tabular}

TABLE 3: Reach dimension.

\begin{tabular}{|c|c|c|}
\hline Dimension number & Choice & Description \\
\hline 1 & Individual & $\begin{array}{l}\text { The mechanism is capable to transfer } \\
\text { knowledge between two individuals } \\
\text { (One-to-one relationship) }\end{array}$ \\
\hline 2 & Project team & $\begin{array}{l}\text { The mechanism is capable to transfer } \\
\text { knowledge to a team (One-to-many } \\
\text { relationship) }\end{array}$ \\
\hline 3 & $\begin{array}{l}\text { Intra-organisational } \\
\text { project teams }\end{array}$ & $\begin{array}{l}\text { The mechanism is capable to transfer } \\
\text { knowledge across numerous teams in } \\
\text { different projects within the same } \\
\text { organisation }\end{array}$ \\
\hline 4 & $\begin{array}{l}\text { Inter-organisational } \\
\text { project teams }\end{array}$ & $\begin{array}{l}\text { The mechanism is capable to transfer } \\
\text { knowledge across numerous teams in } \\
\text { different projects across more than one } \\
\text { organisation }\end{array}$ \\
\hline
\end{tabular}

\section{Flow time dimension}

Flow time pertains to the length of time that is required to transfer knowledge from a sender to a receiver or from one state to another, for example, tacit to explicit (Nissen 2007). The flow time dimension can be seen as short (i.e. fast moving), as well as long (i.e. slow moving), for the knowledge to move between these states and can vary by several orders of magnitude. To operationalise the flow time dimension, Snider and Nissen (2003) divided the flow time in a corresponding scale using highly-granular temporal markers, namely hours, days, months and years. The flow time dimensions can be used for categorising knowledge transfer mechanisms in the sense that certain mechanisms are more suited for quick and in-time transfer of knowledge, that is, face-to-face discussion and email, while other mechanisms are more suited for longer term transfer, that is, post project reviews and best practices.

For this study, the flow time dimensions of Snider and Nissen (2003) are used, namely hours, days, weeks, months and years as described in Table 4.

\section{Synchronicity dimension}

The synchronicity mediation dimension pertains to networks through which knowledge flows, as well as the effect of intermediaries between the sender and receiver of knowledge flows. Hansen (2002) argues that business units that interact and share knowledge with each other in a direct way, thus where the knowledge network path is short, the receiving unit obtains more knowledge and performs better than units where the network paths are longer and more indirect. According to Hansen (2002), longer network paths lead to information distortion, making the search for useful information more difficult, while shorter network paths with direct interaction can more easily share knowledge but are more costly to maintain because of the effort of interaction. Within project teams, time spend on interacting and sharing knowledge is less time spent on project-related activities. Understanding the knowledge transfer mechanism's mediation dimension can aid in the selection of transfer mechanisms that has less knowledge distortion but also require a larger effort to manage.

For this study, the synchronous effect of each knowledge transfer mechanism will be measured according to two options, namely, direct or synchronous mediation versus

TABLE 4: Flow time dimension.

\begin{tabular}{lll}
\hline Dimension number & Choice & Description \\
\hline 1 & Very fast & $\begin{array}{l}\text { The mechanism is capable to transfer } \\
\text { knowledge within hours }\end{array}$ \\
\hline 3 & Fast & $\begin{array}{l}\text { The mechanism is capable to transfer } \\
\text { knowledge within days } \\
4\end{array}$ \\
\hline 5 & Slow & $\begin{array}{l}\text { The mechanism is capable to transfer } \\
\text { knowledge within weeks }\end{array}$ \\
\hline
\end{tabular}


indirect or asynchronous mediation between the sender and the receiver as described in Table 5.

\section{Formalisation dimension}

The formalisation dimension pertains to whether the transfer mechanism is capable of transferring knowledge in a formal or informal way and whether the mechanism can ensure that the knowledge that is transferred can be institutionalised in a formal way or not. Informal knowledge transfer refers to ad-hoc and unstructured knowledge transfer that is typically done in an unplanned, need-toknow and social manner and occurs naturally without external intervention, while formal knowledge transfer is designed to enable the transfer of learning and knowledge in a planned way as typically addressed through the formal structure and routines within organisations and are endorsed by these organisations (Boh 2007; Kitimbo \& Dalkir 2013; Klimkeit 2013). Both formal and informal transfer can take place between persons, as well as though documentation (Boh \& Wong 2013).

For this study, three dimensions are used to evaluate the extent to which a transfer mechanism is capable to transfer the knowledge in a formal way. The three dimensions are described in Table 6.

\section{Valuing knowledge transfer mechanism characteristics Introduction}

To find knowledge transfer mechanism groupings, it had to be researched to what extent each of the identified transfer mechanisms scores on the five characteristic dimensions

\begin{tabular}{lll}
\hline TABLE 5: Mediation dimension. & \\
\hline 1 & Choice & Description \\
\hline $\begin{array}{l}\text { Direct } \\
\text { and/or } \\
\text { synchronously number }\end{array}$ & $\begin{array}{l}\text { The mechanism is capable to transfer } \\
\text { knowledge synchronously. Direct channel } \\
\text { of transfer between the sender and } \\
\text { receiver and the possibility of leading to } \\
\text { a lower degree of distortion of the } \\
\text { knowledge transferred. }\end{array}$ \\
& $\begin{array}{l}\text { Indirect } \\
\text { and/or } \\
\text { asynchronously }\end{array}$ & $\begin{array}{l}\text { Thechanism is capable to transfer } \\
\text { knowledge asynchronously. Mediated } \\
\text { channel of transfer between the sender } \\
\text { and receiver and the possibility of leading } \\
\text { to a higher degree of distortion of the } \\
\text { knowledge transferred. }\end{array}$ \\
\hline &
\end{tabular}

TABLE 6: Formalisation dimension.

\begin{tabular}{lll}
\hline Dimension number & Choice & Description \\
\hline 1 & Informal & $\begin{array}{l}\text { The mechanism is capable to transfer } \\
\text { knowledge in a casual and spontaneous } \\
\text { way. It takes place only when needed and } \\
\text { little accountability is expected of the } \\
\text { knowledge. }\end{array}$ \\
\hline Semi-formal & $\begin{array}{l}\text { The mechanism is capable to transfer } \\
\text { knowledge in a reasonable thought-through } \\
\text { and prepared way, but is done on an ad-hoc } \\
\text { or temporary basis after the sender is } \\
\text { formally requested to do so. Reasonable } \\
\text { accountability is expected of the knowledge. }\end{array}$ \\
& Formal & $\begin{array}{l}\text { The mechanism is capable to transfer } \\
\text { knowledge in a well thought-through and } \\
\text { prepared way and is used as part of a } \\
\text { structured and defined project management } \\
\text { methodology or process. High accountability } \\
\text { is expected of the knowledge. }\end{array}$ \\
\hline &
\end{tabular}

that were discerned in the previous section. The justification and value of the scores cannot solely depend on the opinion of a single person or researcher; therefore, a group of experts is required to provide a combined viewpoint to justify the association.

It seems sensible to apply the Delphi technique in this case. Per definition, a Delphi technique is a structured communication technique that relies on a panel of experts. The experts answer a questionnaire in two or more rounds. After each round, the answers, including a motivation, are summarised in an anonymous way. Through a next round, the experts can review their initial answers in light of the summary of replies from the previous round's panel members. By doing several rounds, it is believed that answers to the questions will converge towards a final answer where after the process is stopped. This full convergence is actually what was not aimed for in this case, as it would diminish variation to a large extent making our next analytical step (categorisation) virtually impossible. In other words, variation was deliberately allowed for. In the next section, we explain the approach taken in this study.

\section{Methodological approach: Expert group}

In this study, an independent expert group was used as reaching of high consensus through multiple rounds would be a highly undesirable outcome especially considering the latent clustering analysis technique for which variation in the data is a necessity. The word 'group' instead of 'panel' is used as the authors would like to stress that to avoid social pressure for consensus, the group members did not physically meet and came to their judgements individually and independently.

A questionnaire was designed using Survey Monkey as a web-based survey tool. A supplement document was also prepared, which listed the 59 transfer mechanisms, as well as a short description of each mechanism to ensure that there would be a common understanding of each mechanism by every expert. Each knowledge transfer mechanisms had to be evaluated against the five characteristic dimensions as described in the previous section. This resulted in a questionnaire comprising of five sections, one for each characteristic dimension, and 59 knowledge transfer mechanisms in each section. Each member of the expert group, therefore, had to individually and independently answer 295 questions related to the knowledge transfer mechanisms and their transfer characteristics. To reduce the possible effect of lost concentration and the emergence of patterns in the answers because of the large number of questions each participant had to answer, the questions in each section of the questionnaire were randomised.

Stitt-Gohdes and Crews (2004) mention that members of an expert group should be knowledgeable about current information and perceptions regarding the topic under investigation, should have experience in it and should be working in such an environment. To meet these criteria, the 
members of the expert group were identified and selected based on their working knowledge and experience into the behaviour of individuals, teams and organisations and have a good understanding of project management processes including events in projects where knowledge transfer takes place. In addition, the members had to have some insight in how knowledge is transferred within and across projects, as well as knowledge and experience in the selection and use of knowledge transfer mechanisms. Members of the expert group were, therefore, selected according to the following criteria:

- Work experience: Members had to have at least 5 years working experience in projects;

- Multiple project experience: Members had to be involved in multiple projects for at least a couple of years to understand knowledge transfer across projects and the mechanisms used;

- Concurrent projects: Members had to have experience of concurrent running projects;

- Management level: Member spectrum need to include people from different management levels, for example, project manager, programme manager or project portfolio manager;

- Industries: Member spectrum need to be from different industries;

- Project Role: Member spectrum must include different project roles, for example, client, contractor, consultant, etc.

- Project size: Member spectrum need to include different project sizes;

- Company size: Member spectrum need to be from different company sizes.

By using the above criteria, 20 experts were identified from different organisations and invited to participate in the study. The questionnaire and the supporting document were sent to each of the identified experts and followed up by email, telephone and instant messaging. From this group, 17 experts responded and individually completed the questionnaire. The demographics of the expert group are depicted in Table 7. From the table, it is evident that the selection of the group did meet the criteria and provided a good representation.

The data collected through the questionnaire were analysed by evaluating the median score, as well as the standard deviation of every item. Although reaching consensus on the individual item level was not a requirement of the research process, it nevertheless showed that on $85 \%$ of the items consensus was reached as indicated by low standard deviation values on the ordinal response data. As such this is an interesting outcome as only the capturing every expert's viewpoint was aimed for. As experts reached consensus on individual items independently from each other, but hopefully not between the items, is a comforting result as fine-grained categorisation otherwise would become very difficult to accomplish empirically for the reason that within variation would become too large.
TABLE 7: Expert group demographics.

\begin{tabular}{|c|c|}
\hline Demographic & Response \\
\hline $\begin{array}{l}\text { Current position in the } \\
\text { organisation }\end{array}$ & $\begin{array}{l}\text { - CEO; } \\
\text { - Manager; } \\
\text { - Portfolio Manager; } \\
\text { - Programme Director; } \\
\text { - Pranager Projects; } \\
\text { - Head of Project Management Office; } \\
\text { - Project Manager; } \\
\text { - Project and Service Manager; } \\
\text { - Senior Manager Cost Estimating; } \\
\text { - Director; } \\
\text { - Technical Specialist; } \\
\text { - Professor. }\end{array}$ \\
\hline $\begin{array}{l}\text { Industry in which the } \\
\text { organisation operates }\end{array}$ & $\begin{array}{l}\text { - Research and Development; } \\
\text { - Information Technology ECM; } \\
\text { - Information Technology (Local Government); } \\
\text { - Education; Financial; } \\
\text { - Energy and Power; } \\
\text { - ICT; } \\
\text { - Business Consulting; } \\
\text { - Petrochemical; } \\
\text { - Professional Services; } \\
\text { - Mining; Engineering Consulting; } \\
\text { - Telecommunications. }\end{array}$ \\
\hline $\begin{array}{l}\text { Number of years } \\
\text { working experience of } \\
\text { the respondent }\end{array}$ & $\begin{array}{l}\text { - Average: } 22 \text { years; } \\
\text { - Range: } 8 \text { years - } 31 \text { years. }\end{array}$ \\
\hline $\begin{array}{l}\text { Number of years involved } \\
\text { in managing multiple sets } \\
\text { of projects }\end{array}$ & $\begin{array}{l}\text { - Average: } 14 \text { years; } \\
\text { - Range: } 5 \text { years }-25 \text { years. }\end{array}$ \\
\hline $\begin{array}{l}\text { Project role of the } \\
\text { respondent }\end{array}$ & $\begin{array}{l}\text { - Portfolio Manager; } \\
\text { - Project Director; } \\
\text { - Project Manager; } \\
\text { - Project Supervisor; } \\
\text { - Consultant; } \\
\text { - Contractor; } \\
\text { - Techt; } \\
\text { - Technical Lead. }\end{array}$ \\
\hline Company size & $\begin{array}{l}\text { - Average: Medium sizes (50-199 employees); } \\
\text { - Range: Very small 5-19 employees) to large (200+ } \\
\text { employees). }\end{array}$ \\
\hline $\begin{array}{l}\text { Number of concurrent } \\
\text { running projects in the } \\
\text { organisation }\end{array}$ & $\begin{array}{l}\text { - Average: } 11-20 \text { projects; } \\
\text { - Range: } 2 \text { to more than } 20 \text { projects. }\end{array}$ \\
\hline $\begin{array}{l}\text { Typical project size in the } \\
\text { organisation }\end{array}$ & $\begin{array}{l}\text { - Average: Large projects (Completed in years, } \\
\$ 1 \mathrm{~m}-\$ 10 \mathrm{~m}) ; \\
\text { - Range: Small (Months, } \$ 10 \mathrm{k}-\$ 100 \mathrm{k} \text { ) to Mega } \\
\text { (Years, >\$10 m). }\end{array}$ \\
\hline
\end{tabular}

\section{A typology of knowledge transfer mechanisms}

\section{Methodological approach: Latent class cluster} analysis

In the previous sections, a state-of-the-art overview of knowledge transfer mechanisms and tools is provided, several dimensions of these tools identified and data collected. The next step is selecting a statistical technique that is suited for multi-dimensional categorisation and gives objective measures to decide on the number of categories fitting the data well. Latent class cluster analysis is the statistical technique selected (Haughton, Legrand \& Woolford 2009). A discussion of the characteristics of this technique is provided below.

Latent classes are unobservable (latent) subgroups or segments (Magidson \& Vermunt 2002). Ideally, variables (in this case, characteristics of knowledge transfer mechanisms and tools) within the same latent class have to be similar on certain criteria, while transfer mechanisms grouped in other different latent classes are dissimilar from each other in certain important ways (Vermunt \& Magidson 2005). Latent class analysis is a statistical analysis technique for finding subtypes of related cases (latent classes) from multivariate 
numeric or categorical data on the basis of maximum likelihood estimation. Latent class analysis may be used to analyse combinations of dichotomous, nominal, ordinal and count variables and uses appropriate distributions for each scale type (Magidson \& Vermunt 2004a). Latent class analysis differs from more traditional approaches such as factor analysis, structural equation models and random-effects regression models as these techniques are severely limited in practice because they require all variables to be continuous, and it uses the assumption of multivariate normality to justify a linear model (Magidson \& Vermunt 2004a).

In latent class analysis, a maximum likelihood algorithm classifies cases (knowledge transfer mechanisms and tools) into clusters based on membership probabilities estimated from a parametric model. The procedure seeks to identify the smallest number of latent (unobservable) classes that is sufficient to account for the relationships among the observed variables (mechanism transfer capability dimensions). The latent variable is to explain all the relationships among the observed variables of its class. The analysis typically starts by fitting a baseline model for but one latent class. If this one-class solution does not fit the data well, the analysis incrementally adds latent classes to the model until the model fit is adequate. The model is evaluated in two ways, namely, model fit and model usefulness. Model fit is determined by statistical means on the basis of a log likelihood criterion, in this case, the Bayesian information criterion (BIC). In short, the BIC provides information about the explanatory power of a model relative to the number of parameters employed. The lower the BIC, the better the fit of the model (Magidson \& Vermunt 2004b). Besides the BIC, the $p$-value ( $p>0.05$, indicating adequate fit) and the number of parameters used (fewest number indicating parsimony). Model usefulness is determined by substantive interpretation of the latent classes and whether they are meaningful to address the underlying questions at hand and through verifying the classification quality by use of classification tables or the use of an entropy criterion to estimate the number of clusters from a model (Celeux \& Soromenho 1996). For this study, a multi-level latent class model prediction was done to determine the best cluster model for the provided data. The higher level in the latent class model consists of the 17 respondents from the expert group and the lower level consisted of the respondent's responses on the different dimension of the transfer mechanisms. By using a multi-level model, the analysis corrected for differences in responses because of a lower consensus on some of the dimensional scoring of the mechanisms.

\section{Clusters of knowledge transfer mechanisms and tools identified}

For the identification of the latent clusters, the software application Latent Gold 4.0 was employed (Vermunt \& Magidson 2005). Summary fit statistics of the models are depicted in Table 8. By using the BIC value as model selection criteria, it can be concluded that a five cluster model has the lowest BIC value of 9930.4362. As there was no other cluster model with the same BIC value, the lowest log likelihood (LL) value, number of parameters (Npar) and Classification error (Class Err) were not needed to as an additional verification of the best cluster fit.

\section{Clusters of knowledge transfer mechanisms and tools profiled}

A profile table for the identified five cluster model is depicted in Table 9. The first row of the table indicates the size of each cluster as a percentage of the respondents. In addition, the other cells in the profile table contain (marginal) conditional probabilities that show how the clusters are related to the indicators, for example, the dimensions of the knowledge transfer mechanism characteristics. For the indicators of an ordinal nature, for example, Explicitness, Reach, Flow Time and Institutionalisation, the mean value of the indicator categories is also provided. The probabilities for each indicator sum up to one: (1) within each cluster. The probability value is interpreted as the respondents chance to choose that specific indicator category within that cluster. For example, respondents in Cluster 1 have a $66.89 \%$ chance of responding that the knowledge transfer mechanisms grouped in this cluster transfer mainly explicit knowledge. The higher the probability value, the more the indicator category belongs to that cluster. In Table 9, the dominant probabilities are shown and indicate the indicator categories belonging to each cluster. The characteristic of each knowledge transfer mechanism cluster will be defined according to these indicator categories, as well as the transfer mechanisms that belong to each identified cluster.

From Table 9, the prevailing characteristics of each cluster are identified by selecting the dominant probability values, as well as evaluating the mean value for every dimension in every cluster. For example, in Cluster 1, the dominant probability is 0.6689 and the mean value is 2.6434 (»3) which corresponds with mainly explicit; therefore, mainly explicit knowledge is transferred by this cluster of mechanisms. The identified clusters, their characteristics as well as associated transfer mechanisms are discussed in more detail in the next section.

TABLE 8: Latent class model prediction summary.

\begin{tabular}{|c|c|c|c|c|}
\hline Latent classes model & $\overline{L L}$ & BIC (LL) & Npar & Class Err \\
\hline 1 Cluster 5-GClass Multilevel & -5431.0896 & 10972.5102 & 16 & 0.0000 \\
\hline 2 Cluster 5-GClass Multilevel & -4996.8948 & 10173.0773 & 26 & 0.0573 \\
\hline 3 Cluster 5-GClass Multilevel & -4887.1635 & 10022.5716 & 36 & 0.0977 \\
\hline 4 Cluster 5-GClass Multilevel & -4812.3177 & 9941.8368 & 46 & 0.0949 \\
\hline 5 Cluster 5-GClass Multilevel & -4772.1390 & $9930.4362 \dagger$ & 56 & 0.0990 \\
\hline 6 Cluster 5-GClass Multilevel & -4755.8250 & 9966.7650 & 66 & 0.1050 \\
\hline
\end{tabular}

GClass, group level classes; LL, log likelihood; BIC (LL), Bayesian information criterion based on log likelihood (The lower the BIC, the better the model); Npar, number of parameters (The fewer, the better the model); Class Err, proposition of classification errors (The lower the better).

$\dagger$, represents the lowest BIC value. 
TABLE 9: Profile table.

\begin{tabular}{|c|c|c|c|c|c|c|}
\hline Indicators & Categories & Cluster 1 & Cluster 2 & Cluster 3 & Cluster 4 & Cluster 5 \\
\hline \multirow[t]{4}{*}{ Explicitness } & 1. Mainly tacit & 0.0255 & 0.2115 & $0.3854 \dagger$ & 0.1254 & 0.1813 \\
\hline & 2. Mainly dualistic & 0.3056 & $0.5384 \dagger$ & $0.4974 \dagger$ & $0.5043 \dagger$ & $0.5328 \dagger$ \\
\hline & 3. Mainly explicit & $0.6689 \dagger$ & 0.2501 & 0.1172 & $0.3703 \dagger$ & 0.2859 \\
\hline & Mean & 2.6434 & 2.0386 & 1.7317 & 2.2449 & 2.1046 \\
\hline \multirow[t]{5}{*}{ Reach } & 1. Individual & 0.0415 & 0.1408 & 0.2771 & 0.0000 & 0.1848 \\
\hline & 2. Team & 0.2266 & $0.3790 \dagger$ & $0.4350 \dagger$ & 0.0004 & $0.4087 \dagger$ \\
\hline & 3. Intra-org & $0.4363 \dagger$ & $0.3599 \dagger$ & 0.2409 & 0.0343 & 0.3189 \\
\hline & 4. Inter-org & 0.2956 & 0.1203 & 0.0470 & $0.9652 \dagger$ & 0.0876 \\
\hline & Mean & 2.9860 & 2.4597 & 2.0577 & 3.9648 & 2.3092 \\
\hline \multirow[t]{5}{*}{ Flow time } & 1. Very fast (hours) & $0.2390 \dagger$ & $0.2844 \dagger$ & $0.6616 \dagger$ & $0.5010 \dagger$ & $0.3120 \dagger$ \\
\hline & 2. Fast (days) & $0.2764 \dagger$ & $0.2910 \dagger$ & 0.2460 & 0.2971 & $0.2973 \dagger$ \\
\hline & 3. Reasonable fast (weeks) & $0.2531 \dagger$ & 0.2358 & 0.0724 & 0.1395 & 0.2244 \\
\hline & 4. Slow (months) & $0.2095 \dagger$ & 0.1727 & 0.0193 & 0.0592 & 0.1530 \\
\hline & 5. Very slow (years) & 0.0220 & 0.0160 & 0.0007 & 0.0032 & 0.0132 \\
\hline \multirow[t]{2}{*}{ Mediation channel } & 1. Direct & 0.0697 & $0.8251 \dagger$ & $0.9767 \dagger$ & 0.4200 & 0.1874 \\
\hline & 2. Indirect & $0.9303 \dagger$ & 0.1749 & 0.0233 & $0.5800 \dagger$ & $0.8126 \dagger$ \\
\hline \multirow[t]{4}{*}{ Institutional } & 1. Informal & 0.0166 & 0.0796 & $0.6960 \dagger$ & 0.2183 & $0.4372 \uparrow$ \\
\hline & 2. Semi-formal & 0.3294 & $0.5458 \dagger$ & 0.2917 & $0.6106 \dagger$ & $0.5045 \dagger$ \\
\hline & 3. Formal & $0.6539 \dagger$ & $0.3746 \dagger$ & 0.0122 & 0.1711 & 0.0583 \\
\hline & Mean & 2.6373 & 2.2950 & 1.3162 & 1.9528 & 1.6211 \\
\hline Cluster size $($ Total $=1)$ : & - & 0.2727 & 0.2701 & 0.2257 & 0.1430 & 0.0884 \\
\hline
\end{tabular}

$\dagger$, represent the dominant probabilities used to define the cluster.

\section{Descriptions of clusters of knowledge transfer mechanisms and tools}

From the multi-level latent class analysis, a frequency count of each knowledge transfer mechanisms belonging to a specific cluster was determined, where the maximum value for the frequency count equalled to 17 (the total number of participants in the expert group). By making use of a Pareto criterion, where the transfer mechanisms in each cluster are sequenced in descending order from highest count to lowest count and then selecting the transfer mechanisms that make up the first $80 \%$ of the total count, the dominant knowledge transfer mechanisms for each cluster were identified with very little overlap of transfer mechanisms between the different clusters. Cluster labels were given to each identified cluster according to the cluster characteristics, as well as the dominant knowledge transfer mechanisms, which form part of each cluster. These clusters labels are discussed in the next sub-sections.

\section{Cluster 1: Formal codification landscape of project-to- project knowledge transfer mechanisms}

Cluster 1 is labelled the formal codification landscape cluster as it includes knowledge transfer mechanisms that deal with the formal capturing of knowledge within an organisation in a methodical and documented way (see Table 10). Knowledge is captured through formal project management methodologies, embedded project management processes and common practices, as well as dedicated and appointed role players. Explicit knowledge is mainly captured through a codification strategy as defined by Hansen et al. (1999), and the flow time of knowledge may vary from hours to months. The channel of transfer is mainly indirect and mediated between the sender and receiver of knowledge, which implies that the knowledge transfer may be limited and distorted because of the actual information that was captured, as well as the possibility of not being able to gain access to the original source of the information. For project-to-project knowledge transfer, this cluster of transfer mechanisms might be sluggish as most transfer will take place through documented systems, embedded processes and formalised methodologies. This cluster also relates to the exploiter landscape or transfer mechanisms as defined by Prencipe and Tell (2001) as it contains ICT-based tools to support project-to-project learning where emphasis is placed on the codification and storage of knowledge during project execution phases to make the knowledge more accessible and exploitable for project members in subsequent projects.

\section{Cluster 2: Training and coaching landscape of project-to- project knowledge transfer mechanisms}

Cluster 2 is labelled the training and coaching landscape cluster as it mainly includes knowledge transfer mechanisms that are directed towards a formal learning approach between projects within an organisation (see Table 11). Learning takes place within a knowledge push environment by either a formal teaching, education, mentorship or apprenticeship programmes or a lesser formal job-rotation, work sessions and site visits. Both tacit and explicit knowledge are transferred through the mechanisms, and the transfer is direct between the sender and receiver and relatively fast. This cluster of mechanisms can be used by organisations to disseminate knowledge to individuals and project teams in order to bring them on par with current practices and needto-knows' or improve their content knowledge in given subject areas where the knowledge base needs to be deepened or broadened as required by the organisation's needs. For project-to-project knowledge transfer, this cluster of transfer 
TABLE 10: Cluster 1 main characteristics and dominant knowledge transfer mechanisms.

\begin{tabular}{|c|c|c|}
\hline Characteristic & Dimension & Dominant mechanisms (frequency count) \\
\hline Explicitness & Mainly explicit & $\begin{array}{l}\text { - Case studies (17) } \\
\text { - Document repositories/databases (17) }\end{array}$ \\
\hline Reach & $\begin{array}{l}\text { Intra- } \\
\text { organisational }\end{array}$ & $\begin{array}{l}\text { - Knowledge sharing boards/bulletin } \\
\text { boards (17) } \\
\text { - Lessons learned logs (17) }\end{array}$ \\
\hline Flow time & $\begin{array}{l}\text { Various (hours } \\
\text { to months) }\end{array}$ & $\begin{array}{l}\text { - Templates and checklists (17) } \\
\text { - Auditors (16) }\end{array}$ \\
\hline Channel & $\begin{array}{l}\text { Indirect } \\
\text { (asynchronously) }\end{array}$ & $\begin{array}{l}\text { - Common practices (16) } \\
\text { - Group support systems/groupware (16) }\end{array}$ \\
\hline Institutionalisation & Formal & $\begin{array}{l}\text { - Project report (16) } \\
\text { - Internal documents (15) } \\
\text { - Intranet (15) } \\
\text { - Knowledge repository (15) } \\
\text { - Project review (14) } \\
\text { - Communities of practice (13) } \\
\text { - Gate-keeper (13) } \\
\text { - Knowledge broker/intermediary (12) } \\
\text { - Work package review (12) } \\
\text { - Case studies (17) }\end{array}$ \\
\hline
\end{tabular}

TABLE 11: Cluster 2 main characteristics and dominant knowledge transfer mechanisms.

\begin{tabular}{|c|c|c|}
\hline Characteristic & Dimension & Dominant mechanisms (frequency count) \\
\hline Explicitness & Mainly dualistic & $\begin{array}{l}\text { - Coaching/mentoring (17) } \\
\text { - Expert consultant (17) }\end{array}$ \\
\hline Reach & $\begin{array}{l}\text { Team to intra- } \\
\text { organisational }\end{array}$ & $\begin{array}{l}\text { - Formal meetings (17) } \\
\text { - Joint exercises (17) }\end{array}$ \\
\hline Flow time & $\begin{array}{l}\text { Fast (hours to } \\
\text { days) }\end{array}$ & $\begin{array}{l}\text { - Teaching (17) } \\
\text { - Training (17) }\end{array}$ \\
\hline Channel & $\begin{array}{l}\text { Direct } \\
\text { (synchronously) }\end{array}$ & $\begin{array}{l}\text { - Apprenticeships/learning by doing/ } \\
\text { learning by using (16) } \\
\text { - Collaborative problem solving (16) }\end{array}$ \\
\hline Institutionalisation & $\begin{array}{l}\text { Semi-formal to } \\
\text { formal }\end{array}$ & $\begin{array}{l}\text { - Job-rotation (16) } \\
\text { - Project briefing/review session (16) } \\
\text { - Stage or phase review (16) } \\
\text { - Team work session (16) } \\
\text { - Job shadowing (15) } \\
\text { - Site visits/project visit (15) } \\
\text { - Cross-training (14) } \\
\text { - Champion visits and change agents (14) }\end{array}$ \\
\hline
\end{tabular}

mechanisms will focus on learning of one project and through a formal learning, mentoring and educational programme transfer this knowledge to members of a receiving project. Such a transfer will be planned and executed in a more formal way.

\section{Cluster 3: Informal person-to-person landscape of project-to-project knowledge transfer mechanisms}

Cluster 3 is labelled the person-to-person landscape cluster and mainly includes knowledge transfer mechanisms that are directed towards people embedded knowledge and the transfer thereof through people-to-people and team-based communications as typically experienced in new product development and research activities that are exploratory of nature (see Table 12). In these types of activities, there is high ambiguity and uncertainty of the knowledge to be transferred, hence the use of face-to-face discussions, brainstorming sessions and informal chatting and document exchange (Cummings \& Teng 2003). The transfer
TABLE 12: Cluster 3 main characteristics and dominant knowledge transfer mechanisms.

\begin{tabular}{lll}
\hline Characteristic & Dimension & Dominant mechanisms (frequency count) \\
\hline Explicitness & Mainly tacit & - Brainstorming sessions (17) \\
& - Dialogue sessions (17) \\
Reach & Team & - Face-to-face (17) \\
Flow time & $\begin{array}{l}\text { Very fast } \\
\text { (hours) }\end{array}$ & - Informal chatting (17) \\
& $\begin{array}{l}\text { Direct } \\
\text { (synchronously) }\end{array}$ & - Sutual caring (17) \\
Channel & Instant messaging (11) \\
& Informal & - Telephone/video conversation (11) \\
Institutionalisation & - Storytelling/narratives (10) \\
& & - Discussion groups (9) \\
& & - Voice/audio mail (9)
\end{tabular}

mechanisms transfer mainly tacit knowledge in a very fast way. The transfer is direct between sender and receiver. Because of the characteristic nature of this cluster, knowledge that is transferred is mainly imbedded in the individual team members and makes the capturing of this knowledge very difficult and informal. This cluster can also be linked to the knowledge personalisation strategy as defined by Hansen et al. (1999), as well as the explorer landscape as defined by Prencipe and Tell (2001) where knowledge is embedded in individuals and mainly transferred through person-to-person interactions. For project-to-project knowledge transfer, this cluster of transfer mechanisms focusses on direct contact and interaction between team members working on different projects.

\section{Cluster 4: Inter-organisational networking landscape of project-to-project knowledge transfer mechanisms}

Cluster 4 is labelled the inter-organisational networking landscape cluster as it mainly includes knowledge transfer mechanisms that are directed towards networking and communication between teams within, as well as across a wider range of organisations (see Table 13). Mechanisms in this cluster transfer mainly explicit knowledge in both direct (email and networking) and indirect (Internet, intranet and wikis) ways. These mechanisms might also be organised to promote knowledge transfer, for example, conferences, seminars and news groups. For project-to-project knowledge transfer, this cluster of transfer mechanisms embraces knowledge sharing and networking between project team members across organisational boundaries through arranged interventions like seminars, conferences, newsgroups and the Internet.

\section{Cluster 5: Intra-organisational communal landscape of project-to-project knowledge transfer mechanisms}

Cluster 5 is labelled the intra-communal landscape cluster and is the weakest cluster as it contains transfer mechanism that do, to a small extent, overlap with other clusters. The cluster includes knowledge transfer mechanisms that are directed towards informal or semi-formal observations or reading, social connection, interaction and discussions within an organisation (see Table 14). Knowledge transferred by these mechanism is a combination of tacit 
TABLE 13: Cluster 4 main characteristics and dominant knowledge transfer mechanisms.

\begin{tabular}{lll}
\hline Characteristic & Dimension & $\begin{array}{l}\text { Dominant mechanisms } \\
\text { (frequency count) }\end{array}$ \\
\hline Explicitness & Mainly explicit & - email (15) \\
& - Conferences (14) \\
Reach & Inter-organisational & - Internet (14) \\
& & - Newsgroups/online forum/ \\
& & web-based discussion (14) \\
Flow time & Very fast (hours) & - Extranet (12) \\
& & - Seminar (11) \\
Channel & Combination & - Wikis (11) \\
& Direct (synchronously) & - Networking (10) \\
& Indirect (asynchronously) & - Metaphors and analogies (7) \\
Institutionalisation & Semi-formal & - Social networks (7) \\
\hline
\end{tabular}

TABLE 14: Cluster 5 main characteristics and dominant knowledge transfer mechanisms.

\begin{tabular}{|c|c|c|}
\hline Characteristic & Dimension & Dominant mechanisms (frequency count) \\
\hline Explicitness & Mainly dualistic & $\begin{array}{l}\text { - Informal document exchange (10) } \\
\text { - Doing within communal context (7) }\end{array}$ \\
\hline Reach & $\begin{array}{l}\text { Team to } \\
\text { intra- } \\
\text { organisational }\end{array}$ & $\begin{array}{l}\text { - Metaphors and analogies (6) } \\
\text { - Observation of practices (6) }\end{array}$ \\
\hline Flow time & $\begin{array}{l}\text { Fast (hours } \\
\text { to days) }\end{array}$ & $\begin{array}{l}\text { - Social networks (5) } \\
\text { - Voice/audio mail (5) }\end{array}$ \\
\hline Channel & $\begin{array}{l}\text { Indirect } \\
\text { (asynchronously) }\end{array}$ & $\begin{array}{l}\text { - Teleconferencing/video-conferencing (4) } \\
\text { - Wikis (4) }\end{array}$ \\
\hline Institutionalisation & $\begin{array}{l}\text { Informal to } \\
\text { semi-formal }\end{array}$ & $\begin{array}{l}\text { - Discussion groups (3) } \\
\text { - Storytelling/narratives (3) }\end{array}$ \\
\hline
\end{tabular}

and explicit and is transferred reasonable fast through mainly indirect ways. Because of its informal nature, the capturing of knowledge for future use may be limited. For project-to-project knowledge transfer, this cluster of transfer mechanisms builds on the social connectivity between team members working on different projects through informal document exchange, social networking, observation of practices, audio and teleconferencing, etc.

\section{Conclusion}

This research originated from the notion that in a projectised world, there is a growing importance of knowledge for project-based organisations to deliver new products and services in competitive markets. The need for project-based learning in these organisations requires the efficient codification and transfer of knowledge across project boundaries. Considering the wide range of knowledge transfer mechanisms available for project-toproject knowledge transfer, the research aimed to refine the classification of available knowledge transfer mechanisms through the identification of a typology consisting of a smaller number of knowledge mechanism groups that would help practitioners choose the right knowledge transfer mechanisms for their projects. The research process followed three definitive steps: (1) to determine from literature the current available knowledge transfer mechanisms and tools, (2) to identify from literature appropriate dimensions to group mechanisms together and (3) empirically derive knowledge transfer clusters according to their similar characteristics.
In answering the research questions, the main findings are as follows: Firstly, through a systematic overview of recent literature in the field, a current list of available knowledge transfer mechanisms were identified, as well as a set of five dimensions that could be used to classify the knowledge transfer mechanisms. Secondly, using latent class analysis on the inputs from an expert group, the authors could successfully identify five clusters of knowledge transfer mechanisms that could be used by project practitioners to choose between the wide spectrum of mechanisms, each cluster with its specific characteristics. In summary, the clusters are characterised as: (1) the formal codification landscape - dealing with the formal capturing of knowledge in in a methodological way, (2) the training and coaching landscape - with knowledge mechanisms directed towards a formal learning approach between projects, (3) the person-toperson landscape - that is, people-to-people and team-based communication, (4) the inter-organisational networking landscape - networks of communications between teams within and across a range of organisations and (5) the intraorganisational communal landscape - informal/semi-formal reading, social connection, interaction and discussion within an organisation.

The findings from the research make a clear contribution to the field of project-to-project knowledge transfer. Firstly, an updated overview of available knowledge transfer mechanisms used by project-based organisations was produced and is available to both researchers and practitioners for further use. Secondly, a structured set of dimensions whereby knowledge transfer mechanisms can be classified in specific groups were added to the literature. The key contribution of this research to the field of project-toproject knowledge transfer is a newly defined typology of knowledge transfer mechanisms and tools, each element of the typology exhibiting a number of specific common characteristics that identifies a group of mechanisms and tools as unique and appropriate for specific project knowledge transfer conditions.

From a theoretical point of view, the study acknowledges that knowledge transfer mechanisms are complex (social) phenomena for which multiple dimensions should be distinguished if one choses to study them. Furthermore, an important strength of this study concerns its use of a multimethod approach, in which a systematic literature review is combined with the use of expert interviews and latent class analysis. This approach provides a more holistic understanding of phenomenon under study. Nevertheless, it is important to consider any possible uncertainties pertaining to the research, namely the sample size of the expert group and the coupled way the expert group was consulted. Although the sample size of project experts seems to be relatively small, two aspects should be considered. Firstly, it could be argued that more participants in the expert group would be advantageous. This is not always desirable as in the case of this research it aimed for variability in expert opinion, and the authors were, therefore, satisfied that the level of variability in the responses already delivered the required 
results. Secondly, the authors acknowledge that future studies could consider larger sample sizes.

What are the implications of the newly identified typology for project practitioners? We already pointed out that project managers face a very wide range of project-toproject knowledge transfer mechanisms from which to select the appropriate set of mechanisms for optimum project performance. Based on the needs of the specific type or class of project under consideration, a project manager can select appropriate mechanisms by comparing the project needs with the characteristics exhibited by the five clusters. This will reduce the effort and risk of wrong transfer mechanisms selection substantially. The more experienced project manager will probably find the task of selection easier than the lesser experienced project managers.

Efficient and successful across project knowledge transfer can be considered as a combination of the characteristics and the type of knowledge being transferred and the transfer mechanisms and tools used. Future research could try to sort out which combinations of knowledge types and knowledge transfer mechanisms lead to satisfactory transfer results and could investigate the appropriate matching of specific clusters and their characteristics to the needs of specific types or classes of projects.

\section{Acknowledgements}

The authors wish to thank Prof. Jeroen K. Vermunt from the Department of Methods and Statistics at Tilburg University in the Netherlands, for providing advice and help in the performing of the multi-level latent class analysis. They also thank the associate editor and two anonymous reviewers for their constructive feedback.

\section{Competing interests}

The authors declare that they have no financial or personal relationship(s) that may have inappropriately influenced them in writing this article.

\section{Authors' contributions}

C.V.W. contributed to most of the writing. L.O. contributed to statistical analyses and co-writing. T.P. contributed to cowriting.

\section{References}

Aghaei Chadegani, A., Salehi, H., Md Yunus, M.M., Farhadi, H., Fooladi, M., Farhadi, M. et al., 2013, 'A comparison between two main academic literature collections: Web of Science and Scopus databases', Asian Social Science 9(5), 18-26. https:// doi.org/10.5539/ass.v9n5p18

Ajmal, M.M. \& Koskinen, K.U., 2008, 'Knowledge transfer in project-based organizations: an organizational culture perspective', Project Management Journal 39(1), 7-15. https://doi.org/10.1002/pmj.20031

Akgün, A.E., Lynn, G.S., Keskin, H. \& Dogan, D., 2014, 'Team learning in IT implementation projects: Antecedents and consequences', International Journal of Information Management 34(1), 37-47. https://doi.org/10.1016/j.ijinfomgt. 2013.09.007

Akram, A., 2009, 'The importance of knowledge transfer in decision making', Communications of the IIMA 9(3), 39-50.
Alavi, M. \& Leidner, D.E., 2001, 'Knowledge management and knowledge management systems: Conceptual foundations and research issues', MIS Quarterly 25(1), 107-136. https://doi.org/10.2307/3250961

Ambos, T.C. \& Ambos, B., 2009, 'The impact of distance on knowledge transfer effectiveness in multinational corporations', Journal of International Management 15(1), 1-14. https://doi.org/10.1016/j.intman.2008.02.002

Andriopoulos, C. \& Lewis, M.W., 2009, 'Exploitation-exploration tensions and organizational ambidexterity: Managing paradoxes of innovation', Organization Science 20(4), 696-717. https://doi.org/10.1287/orsc.1080.0406

Anne-Mette, L. \& Ebba Holme, H., 2011, 'Knowledge-sharing enablers and barriers in pharmaceutical research and development', Journal of Knowledge Management 15(1), 53-70. https://doi.org/10.1108/13673271111108693

Argote, L. \& Ingram, P., 2000, 'Knowledge transfer: A basis for competitive advantage in firms', Organizational Behavior and Human Decision Processes 82(1), 150-169. https://doi.org/10.1006/obhd.2000.2893

Argote, L., McEvily, B. \& Reagans, R., 2003, 'Managing knowledge in organizations: An integrative framework and review of emerging themes', Management Science 49(4), 571-582. https://doi.org/10.1287/mnsc.49.4.571.14424

Bakker, R.M., Cambré, B., Korlaar, L. \& Raab, J., 2011, 'Managing the project learning paradox: A set-theoretic approach toward project knowledge transfer', International Journal of Project Management 29(5), 494-503. https://doi.org/ 10.1016/j.ijproman.2010.06.002

Barney, J.B., 2001, 'Resource-based theories of competitive advantage: A ten-year retrospective on the resource-based view', Journal of Management 27(6), 643-651. https://doi.org/10.1177/014920630102700602

Bartsch, V., Ebers, M. \& Maurer, I., 2013, 'Learning in project-based organizations: The role of project teams' social capital for overcoming barriers to learning', International Journal of Project Management 31(2), 239-251. https://doi.org/ 10.1016/j.ijproman.2012.06.009

Boh, W.F., 2007, 'Mechanisms for sharing knowledge in project-based organizations', Information and Organization 17(1), 27-58. https://doi.org/10.1016/j.infoandorg. 2006.10.001

Boh, W.F. \& Wong, S.S., 2013, 'Organizational climate and perceived manager effectiveness: Influencing perceived usefulness of knowledge sharing mechanisms', Journal of the Association of Information Systems 14(3), 122-152.

Borgatti, S.P. \& Cross, R., 2003, 'A Relational view of information seeking and learning in social networks', Management Science 49(4), 432-445. https://doi.org/ 10.1287/mnsc.49.4.432.14428

Brachos, D., Kostopoulos, K., Soderquist, K.E. \& Prastacos, G., 2007, 'Knowledge effectiveness, social context and innovation', Journal of Knowledge Management 11(5), 31-44. https://doi.org/10.1108/13673270710819780

Cantner, U., Joel, K. \& Schmidt, T., 2009, 'The use of knowledge management by German innovators', Journal of Knowledge Management 13(4), 187-203. https:// doi.org/10.1108/13673270910971923

Cao, Q. \& Hoffman, J.J., 2011, 'A case study approach for developing a project performance evaluation system', International Journal of Project Management 29(2), 155-164. https://doi.org/10.1016/j.ijproman.2010.02.010

Celeux, G. \& Soromenho, G., 1996, 'An entropy criterion for assessing the number of clusters in a mixture model', Journal of Classification 13(3), 195-212. https://doi. org/10.1007/BF01246098

Chilton, M.A. \& Bloodgood, J.M., 2010, 'Adaption-innovation theory and knowledge use in organizations', Management Decision 48(8), 1159-1180. https://doi. use in organizations', Management
org/10.1108/00251741011076726

Christensen, K.S. \& Bukh, P.N., 2012, 'Facts, processes and common understandings: The management of knowledge in project based organisations', in H.-T. Hou (ed.), New research on knowledge management application and lesson learned, p. 47, InTech, Rijeka, Croatia.

Conklin, J., 2001, Designing organizational memory: Preserving Intellectual assets in a knowledge economy, CogNexus Institute, viewed n.d., from http://cognexus.org

Cooper, R.G. \& Edgett, S.J., 2012, 'Best practices in the idea-to-launch process and its governance', Research-Technology Management 55(2), 43-54. https://doi. org/10.5437/08956308X5502022

Cummings, J.L. \& Teng, B.-S., 2003, 'Transferring R\&D knowledge: The key factors affecting knowledge transfer success', Journal of Engineering \& Technology Management 20(1/2), 39-68. https://doi.org/10.1016/S0923-4748(03)00004-3

Daigle-LeBlanc, M.B. \& Kelloway, E.K., 2002, Measuring knowledge use in organizations, Saint Mary's University, Halifax, Nova Scotia, Canada.

d'Armagnac, S., 2014, 'Issues in the management of embedded knowledge in projectbased organizations: The project actor's role', Knowledge Management Research \& Practice 13(4), 446-462. https://doi.org/10.1057/kmrp.2013.62

Delen, D., Zaim, H., Kuzey, C. \& Zaim, S., 2013, 'A comparative analysis of machine learning systems for measuring the impact of knowledge management practices', Decision Support Systems 54(2), 1150-1160. https://doi.org/10.1016/j.dss.2012. 10.040

Disterer, G., 2002, 'Management of project knowledge and experiences', Journal of Knowledge Management 6(5), 512-520. https://doi.org/10.1108/13673270 210450450

Duffield, S. \& Whitty, S.J., 2015, 'Developing a systemic lessons learned knowledge model for organisational learning through projects', International Journal of Project Management 33(2), 311-324. https://doi.org/10.1016/j.ijproman. 2014.07.004

Eriksson, P.E., 2013, 'Exploration and exploitation in project-based organizations: Development and diffusion of knowledge at different organizational levels in construction companies', International Journal of Project Management 31(3), 333-341. https://doi.org/10.1016/j.ijproman.2012.07.005 
Eze, U.C., Goh, G.G.G., Goh, C.Y. \& Tan, T.L., 2013, 'Perspectives of SMEs on knowledge sharing', Vine 43(2), 210-236. https://doi.org/10.1108/03055721311329963

Frank, A.G., Ribeiro, J.L.D. \& Echeveste, M.E., 2015, 'Factors influencing knowledge transfer between NPD teams: A taxonomic analysis based on a sociotechnical approach', R\&D Management 45(1), 1-22. https://doi.org/10.1111/radm.12046

Gann, D.M. \& Salter, A.J., 2000, 'Innovation in project-based, service-enhanced firms: The construction of complex products and systems', Research Policy 29(7-8) 955-972. https://doi.org/10.1016/S0048-7333(00)00114-1

Gasik, S., 2011, 'A model of project knowledge management', Project Management Journal 42(3), 23-44. https://doi.org/10.1002/pmj.20239

Godenhjelm, S., Lundin, R.A. \& Sjöblom, S., 2015, 'Projectification in the public sector - The case of the European Union', International Journal of Managing Projects in Business 8(2), 324-348. https://doi.org/10.1108/IJMPB-05-2014-0049

Grabher, G., 2004, 'Learning in projects, remembering in networks?: Communality, sociality, and connectivity in project ecologies', European Urban and Regional Studies 11(2), 103-123. https://doi.org/10.1177/0969776404041417

Graham, I.D., Logan, J., Harrison, M. B., Straus, S.E., Tetroe, J., Caswell, W., et al., 2006 'Lost in knowledge translation: Time for a map?', Journal of Continuing Education in the Health Professions 26(1), 13-24. https://doi.org/10.1002/chp.47

Grant, R.M., 1996, 'Towards a knowledge-based theory of the firm', Strategic Management Journal 17(Winter Special), 109-122.

Gupta, S. \& Polonsky, M., 2014, 'Inter-firm learning and knowledge-sharing in multinational networks: An outsourced organization's perspective', Journal of
Business Research 67(4), 615-622. https://doi.org/10.1016/j.jbusres.2013.02.043

Hansen, M.T., 2002, 'Knowledge networks: Explaining effective knowledge sharing in multiunit companies', Organization Science 13(3), 232-248. https://doi. org/10.1287/orsc.13.3.232.2771

Hansen, M.T., Nohria, N. \& Tierney, T., 1999, 'What's your strategy for managing knowledge?', Harvard Business Review 77(2), 106-116.

Haughton, D., Legrand, P. \& Woolford, S., 2009, 'Review of three latent class cluster analysis packages: Latent Gold, poLCA, and MCLUST', The American Statistician 63(1), 81-91. https://doi.org/10.1198/tast.2009.0016'

Heisig, P., 2009, 'Harmonisation of knowledge management - comparing $160 \mathrm{KM}$ frameworks around the globe', Journal of Knowledge Management 13(4), 4-31. frameworks around the globe', Journal of Knowlt
https://doi.org/10.1108/13673270910971798

Hobday, M., 2000, 'The project-based organisation: An ideal form for managing complex products and systems?', Research Policy 29(7-8), 871-893. https://doi. org/10.1016/S0048-7333(00)00110-4

Holzmann, V., 2013, 'A meta-analysis of brokering knowledge in project management', International Journal of Project Management 31(1), 2-13. https://doi. org/10.1016/j.ijproman.2012.05.002

Hong, J.F.L. \& Nguyen, T.V., 2009, 'Knowledge embeddedness and the transfer mechanisms in multinational corporations', Journal of World Business 44(4), 347-356. https://doi.org/10.1016/j.jwb.2009.01.001

Jafari, M., Rezaeenour, J., Mohammad Mahdavi, M. \& Atefe, H., 2011, 'Development and evaluation of a knowledge risk management model for project-based organizations', Management Decision 49(3), 309-329. https://doi.org/10.1108/ 00251741111120725

Jasimuddin, S.M., 2007, 'Exploring knowledge transfer mechanisms: The case of a UKbased group within a high-tech global corporation', International Journal of Information Management 27(4), 294-300. https://doi.org/10.1016/j.ijinfomgt. 2007.03.003

Jasimuddin, S.M., Connell, C. \& Klein, J.H., 2014, 'A decision tree conceptualization of choice of knowledge transfer mechanism: The views of software development specialists in a multinational company', Journal of Knowledge Management 18(1) 194-215. https://doi.org/10.1108/JKM-05-2013-0195

Jasimuddin, S.M. \& Zhang, Z., 2009, 'The symbiosis mechanism for effective knowledge transfer', Journal of the Operational Research Society 60(5), 706-716. https://doi.org/10.1057/palgrave.jors.2602613

Jennex, M.E., 2008, Current issues in knowledge management, Information Science Reference, Hershey, PA, IGI Global.

Jeon, S., Kim, Y.-G. \& Koh, J., 2011, 'An integrative model for knowledge sharing in communities-of-practice', Journal of Knowledge Management 15(2), 251-269. https://doi.org/10.1108/13673271111119682

Jugdev, K. \& Wishart, P., 2014, 'Mutual caring - Resolving habituation through awareness: Supporting meaningful learning from projects', Project Management Journal 45(2), 66-82. https://doi.org/10.1002/pmj.21406

Kitimbo, I. \& Dalkir, K., 2013, 'Learning from project experience: Creating, capturing and sharing knowledge', Knowledge Management: An International Journal 12(4) 59-74. https://doi.org/10.18848/2327-7998/cgp/v12i04/50810

Klimkeit, D., 2013, 'Organizational context and collaboration on international projects: The case of a professional service firm', International Journal of Project Management 31(3), 366-377. https://doi.org/10.1016/j.ijproman.2012.08.001

Kraaijenbrink, J., Spender, J.-C. \& Groen, A.J., 2010, 'The resource-based view: A review and assessment of its critiques', Journal of Management 36(1), 349-372. https://doi.org/10.1177/0149206309350775

Lee, K.C., Lee, S. \& Kang, I.W., 2005, 'KMPI: Measuring knowledge management performance, Information and Management 42(3), 469-482. https://doi. org/10.1016/j.im.2004.02.003

Levering, R., Ligthart, R., Noorderhaven, N. \& Oerlemans, L., 2013, 'Continuity and change in interorganizational project practices: The Dutch shipbuilding industry 1950-2010', International Journal of 31(5), 735-747. https://doi.org/10.1016/j. ijproman.2012.12.010
Love, P.E., Edum-Fotwe, F. \& Irani, Z., 2003, 'Management of knowledge in project environments', International Journal of Project Management 21(3), 155-156. environments', International Journal of Project
https://doi.org/10.1016/S0263-7863(02)00089-3

Magidson, J. \& Vermunt, J.K., 2002, 'Latent class models for clustering: A comparison with K-means', Canadian Journal of Marketing Research 20(1), 37-44.

Magidson, J. \& Vermunt, J.K., 2004a, 'Comparing latent class factor analysis with the traditional approach in data mining', in H. Bozdogan (ed.), Statistical data mining \& knowledge discovery, pp. 373-383, Chapman \& Hall/CRC, Boca Raton, London, New York, Washington, DC

Magidson, J. \& Vermunt, J.K., 2004b, 'Latent class models', in D. Kaplan (ed.), The Sage handbook of quantitative methodology for the social sciences, pp. 175-192, Sage Publications, Thousand Oaks, CA.

Manning, S. \& Sydow, J., 2007, 'Transforming creative potential in project networks: How TV movies are produced under network-based control', Critical Sociology 33(1), 19-42. https://doi.org/10.1163/156916307X168575

Markus, M.L., 2001, 'Towards a theory of knowledge reuse: Types of knowledge reuse situations and factors in reuse success', Journal of Management Information
Systems 18(1), 57-93. https://doi.org/10.1080/07421222.2001.11045671

Nidhra, S., Yanamadala, M., Afzal, W. \& Torkar, R., 2013, 'Knowledge transfer challenges and mitigation strategies in global software development - A systematic literature review and industrial validation', International Journal of Information Management 33(2), 333-355. https://doi.org/10.1016/j.ijinfomgt. Information

Nissen, M.E., 2007, 'Knowledge management and global cultures: Elucidation through an institutional knowledge-flow perspective', Knowledge and Process an institutional knowledge-flow perspective, Knowledge
Management 14(3), 211-225. https://doi.org/10.1002/kpm.285

Nonaka, I., 1994, 'A dynamic theory of organizational knowledge creation', Organization Science 5(1), 14-37. https://doi.org/10.1287/orsc.5.1.14

Nonaka, I., 2007, 'The knowledge-creating company', Harvard Business Review 85(7/8), 162-171.

Ortega, J., 2001, 'Job rotation as a learning mechanism job rotation as a learning mechanism', Management Science 47(10), 1361-1370. https://doi.org/10.1287/ mnsc.47.10.1361.10257

Packendorff, J. \& Lindgren, M., 2014, 'Projectification and its consequences: Narrow and broad conceptualisations', South African Journal of Economic and Management Sciences 17(1), 7-21. https://doi.org/10.4102/sajems.v17i1.807

Patriotta, G., Castellano, A. \& Wright, M., 2013, 'Coordinating knowledge transfer: Global managers as higher-level intermediaries', Journal of World Business 48(4), 515-526. https://doi.org/10.1016/j.jwb.2012.09.007

Peltokorpi, V. \& Tsuyuki, E., 2006, 'Knowledge governance in a Japanese project-based organization', Knowledge Management Research \& Practice 4(1), 36-45. https:// doi.org/10.1057/palgrave.kmrp.8500080

Penrose, E., 1959, The theory of the growth of the firm, John Wiley \& Sons, New York. Petter, S., Mathiassen, L. \& Vaishnavi, V., 2007, 'Five keys to project knowledge sharing', IT Professional Magazine 9(3), 42-46. https://doi.org/10.1109/MITP.2007.44

Prencipe, A. \& Tell, F., 2001, 'Inter-project learning: Processes and outcomes of knowledge codification in project-based firms', Research Policy 30(9), 1373-1394. https://doi.org/10.1016/S0048-7333(01)00157-3

Ruuska, I. \& Vartiainen, M., 2005, 'Characteristics of knowledge sharing communities in project organizations', International Journal of Project Management 23(5), in project organizations', International Journal of Project
374-379. https://doi.org/10.1016/j.ijproman.2005.01.003

Sáenz, J., Aramburu, N. \& Blanco, C.E., 2012, 'Knowledge sharing and innovation in Spanish and Colombian high-tech firms', Journal of Knowledge Management 16(6), 919-933. https://doi.org/10.1108/13673271211276191

Schulze, A., Brojerdi, G. \& von Krogh, G., 2014, 'Those who know, do. Those who understand, teach. Disseminative capability and knowledge transfer in the automotive industry', Journal of Product Innovation Management 31(1), 79-97. https://doi.org/10.1111/jpim.12081

Snider, K.F. \& Nissen, M.E., 2003, 'Beyond the body of knowledge: A knowledge-flow approach to project management theory and practice', Project Management Journal 34(2), 4

Stitt-Gohdes, W.L. \& Crews, T.B., 2004, 'The Delphi technique: A research strategy for career and technical education', Journal of Career and Technical Education 20(2), 55-67. https://doi.org/10.21061/jcte.v20i2.636

Straus, S., Tetroe, J. \& Graham, I.D., 2009, Knowledge translation in health care: Moving from evidence to practice, 1st edn., John Wiley \& Sons, West Sussex.

Straus, S., Tetroe, J. \& Graham, I.D., 2013, Knowledge translation in health care: Moving from evidence to practice, 2nd edn., John Wiley \& Sons, West Sussex.

Tashakkori, A. \& Teddlie, C., 1998, Mixed methodology: Combining qualitative and quantitative approaches, Sage, Thousand Oaks, CA.

Teo, T.S.H. \& Bhattacherjee, A., 2014, 'Knowledge transfer and utilization in IT outsourcing partnerships: A preliminary model of antecedents and outcomes', Information \& Management 51(2), 177-186. https://doi.org/10.1016/j. im.2013.12.001

Van Donk, D.P. \& Riezebos, J., 2005, 'Exploring the knowledge inventory in projectbased organisations: A case study', International Journal of Project Management 23(1), 75-83. https://doi.org/10.1016/j.ijproman.2004.05.002

Vermunt, J.K. \& Magidson, J., 2005, Latent Gold 4.0 User's Guide, Statistical Innovations Inc., Belmont, MA.

Vom Brocke, J. \& Lippe, S., 2015, 'Managing collaborative research projects: A synthesis of project management literature and directives for future research', International Journal of Project Management 33(5), 1022-1039. https://doi. org/10.1016/j.ijproman.2015.02.001 
Whittington, R., Pettigrew, A., Peck, S., Fenton, E. \& Conyon, M., 1999, 'Change and complementarities in the new competitive landscape: A European panel study 1992 1996', Organization Science 10(5), 583-600. https://doi.org/10.1287/orsc.10.5.583

Whyte, J., Ewenstein, B., Hales, M. \& Tidd, J., 2008, 'Visualizing knowledge in projectbased work', Long Range Planning 41(1), 74-92. https://doi.org/10.1016/j. Irp.2007.10.006

Wickramasinghe, V. \& Widyaratne, R., 2012, 'Effects of interpersonal trust, team leader support, rewards, and knowledge sharing mechanisms on knowledge leader support, rewards, and knowledge sharing mechanisms on knowledge
sharing in project teams', VINE 42(2), 214-236. https://doi.org/10.1108/03 sharing in project
055721211227255
Winch, G.M., 2014, 'Three domains of project organising', International Journal of Project Management 32(5), 721-731. https://doi.org/10.1016/j.ijproman.2013. 10.012

Yang, L.-R., Chen, J.-H. \& Wang, H.-W., 2012, 'Assessing impacts of information technology on project success through knowledge management practice', Automation in Construction 22(0), 182-191. https://doi.org/10.1016/j.autcon. 2011.06.016

Zollo, M. \& Winter, S.G., 2002, 'Deliberate learning and the evolution of dynamic capabilities', Organization Science 13(3), 339-351. https://doi.org/10.1287/ orsc.13.3.339.2780 


\section{Appendix 1}

TABLE 1-A1: Identified knowledge transfer mechanisms.

\begin{tabular}{|c|c|c|}
\hline Number & Mechanism name & Mechanism description \\
\hline 1 & Apprenticeships & $\begin{array}{l}\text { Transferring knowledge by training a new generation of } \\
\text { practitioners in a certain trade or profession through learning by } \\
\text { doing and learning by using. }\end{array}$ \\
\hline 2 & Auditors & $\begin{array}{l}\text { Transferring knowledge by auditors through findings and } \\
\text { observations during formal audits. }\end{array}$ \\
\hline 3 & Brainstorming sessions & $\begin{array}{l}\text { Transferring knowledge through group wise thinking, idea sharing } \\
\text { and participation. }\end{array}$ \\
\hline 4 & Case studies & $\begin{array}{l}\text { Transferring knowledge through a up-close, in-depth, and detailed } \\
\text { examination of a project or subject case. }\end{array}$ \\
\hline 5 & $\begin{array}{l}\text { Champion visits and change } \\
\text { agents }\end{array}$ & $\begin{array}{l}\text { Transferring knowledge by a person that persuades project } \\
\text { members to adopt practices that are not only new, but also break } \\
\text { with the norms of the institutional environment. }\end{array}$ \\
\hline 6 & Coaching/mentoring & $\begin{array}{l}\text { Transferring knowledge through training or development in which } \\
\text { an individual person (coach) supports a learner in achieving a } \\
\text { specific personal or professional goal. }\end{array}$ \\
\hline 7 & Collaborative problem solving & $\begin{array}{l}\text { Transferring knowledge through knowledge exchange between } \\
\text { team members and decision makers (work package or project } \\
\text { managers). }\end{array}$ \\
\hline 8 & Common practices & $\begin{array}{l}\text { Transferring knowledge through the use of common best practices } \\
\text { and methodologies. }\end{array}$ \\
\hline 9 & Communities of practice & $\begin{array}{l}\text { Transferring knowledge through the sharing of ideas within a group } \\
\text { of people that share a common interest or profession. }\end{array}$ \\
\hline 10 & Conferences & $\begin{array}{l}\text { Transferring knowledge through attending presentation on a } \\
\text { specific topic and networking between people. }\end{array}$ \\
\hline 11 & Cross-training & $\begin{array}{l}\text { Transferring knowledge through the learning of a new skill or job } \\
\text { that compliments one's existing skills. }\end{array}$ \\
\hline 12 & Dialogue sessions & $\begin{array}{l}\text { Transferring knowledge through a verbal or written conversation } \\
\text { between two people directed towards exploration of a subject or } \\
\text { resolution of a problem. }\end{array}$ \\
\hline 13 & Discussion groups & $\begin{array}{l}\text { Transferring knowledge through discussing (in speech or writing) } \\
\text { various facts, opinions, and issues relating to the treatment of a } \\
\text { subject. }\end{array}$ \\
\hline 14 & $\begin{array}{l}\text { Document repositories/ } \\
\text { databases }\end{array}$ & $\begin{array}{l}\text { Transferring knowledge through searching for and using information } \\
\text { stored in repositories and databases. }\end{array}$ \\
\hline 15 & $\begin{array}{l}\text { Doing within communal } \\
\text { context }\end{array}$ & $\begin{array}{l}\text { Transferring knowledge through the learning by doing within a } \\
\text { social unit that shares common values. }\end{array}$ \\
\hline 16 & email & $\begin{array}{l}\text { Transferring knowledge through sending textual messages with } \\
\text { information (with or without attached files) to one or more } \\
\text { recipients via a computer network or the Internet. }\end{array}$ \\
\hline 17 & Expert consultant & $\begin{array}{l}\text { Transferring knowledge through the use of expert advice or services } \\
\text { in a specific field of practice. }\end{array}$ \\
\hline 18 & Extranet & $\begin{array}{l}\text { Transferring knowledge through a controlled computer network } \\
\text { extending beyond the current organisation, for example, including } \\
\text { sub-contractors and vendors. }\end{array}$ \\
\hline 19 & Face-to-face & $\begin{array}{l}\text { Transferring knowledge through face-to-face communication } \\
\text { between individuals that are in each other's presence. }\end{array}$ \\
\hline 20 & Formal meetings & $\begin{array}{l}\text { Transferring knowledge through a formal act of assembling or } \\
\text { coming together of a group of people for a purpose of discussion or } \\
\text { decision making. }\end{array}$ \\
\hline 21 & Gate-keeper & $\begin{array}{l}\text { Transferring knowledge through a person that controls project } \\
\text { continuation and access to individuals, teams and other resources. }\end{array}$ \\
\hline 22 & $\begin{array}{l}\text { Group support systems/ } \\
\text { groupware }\end{array}$ & $\begin{array}{l}\text { Transferring knowledge through a computer programme or group of } \\
\text { programmes designed to facilitate collaborative working by } \\
\text { different project team members and other users. }\end{array}$ \\
\hline 23 & Informal chatting & $\begin{array}{l}\text { Transferring knowledge through an informal familiar and easy talk } \\
\text { or easy conversation, verbally or written, between two people. }\end{array}$ \\
\hline 24 & Informal document exchange & $\begin{array}{l}\text { Transferring knowledge through the exchange of informal, unofficial } \\
\text { or work documents for the purpose of exchanging information } \\
\text { during the execution of project activities. }\end{array}$ \\
\hline 25 & Informal meetings & $\begin{array}{l}\text { Transferring knowledge through an informal act of assembling or } \\
\text { coming together of a group of people for a purpose of discussion or } \\
\text { decision making. }\end{array}$ \\
\hline 26 & Instant messaging & $\begin{array}{l}\text { Transferring knowledge through the process of sending an in-time } \\
\text { message or messages using a certain messaging platform, for } \\
\text { example, SMS or WhatsApp. }\end{array}$ \\
\hline 27 & Internal documents & $\begin{array}{l}\text { Transferring knowledge through the use of semi-formal inside the } \\
\text { organisational documents. }\end{array}$ \\
\hline 28 & Internet & $\begin{array}{l}\text { Transferring knowledge through the use of a global computer } \\
\text { network which provides a variety of information. Typically called } \\
\text { the World Wide Web. }\end{array}$ \\
\hline 29 & Intranet & $\begin{array}{l}\text { Transferring knowledge through a local or restricted computer } \\
\text { network that is only accessible from within an organisation. }\end{array}$ \\
\hline 30 & Job-rotation & $\begin{array}{l}\text { Transferring knowledge through doing a variety of tasks on a } \\
\text { rotation basis in order to learn from them. }\end{array}$ \\
\hline
\end{tabular}

Citations

(Christensen \& Bukh 2012; Cummings \& Teng 2003; Gann \& Salter 2000; Hansen et al. 1999; Jafari et al. 2011)

(Patriotta et al. 2013)

(Jasimuddin et al. 2014)

(Teo \& Bhattacherjee 2014)

(Patriotta et al. 2013; Straus, Tetroe \& Graham 2013)

(Jafari et al. 2011)

(Graham et al. 2006; Wickramasinghe \& Widyaratne 2012

(Boh 2007)

(Boh 2007; Boh \& Wong 2013; Jeon et al. 2011; Jugdev \& Wishart 2014; Ruuska \& Vartiainen 2005)

(Patriotta et al. 2013)

(Boh \& Wong 2013; Patriotta et al. 2013)

(Boh \& Wong 2013; Petter, Mathiassen \& Vaishnavi 2007)

(Gasik 2011; Patriotta et al. 2013)

(Boh 2007; Boh \& Wong 2013; Petter et al. 2007)

(Jasimuddin \& Zhang 2009)

(Jennex 2008; Wickramasinghe \& Widyaratne 2012)

(Boh 2007; Markus 2001)

(Eze et al. 2013

(Gasik 2011; Jugdev \& Wishart 2014)

Gasik 2011; Hong \& Nguyen 2009; Wickramasinghe \& Widyaratne 2012)

(Cooper \& Edgett 2012; Patriotta et al. 2013;)

(Eze et al. 2013)

(Boh \& Wong 2013; Patriotta et al. 2013; Petter et al. 2007; Wickramasinghe \& Widyaratne 2012)

(Boh \& Wong 2013)

Akgün et al. 2014; Andriopoulos \& Lewis 2009; Borgatti \& Cross 2003; Lee, Lee \& Kang 2005)

(Boh 2007; Jasimuddin 2007)

(Peltokorpi \& Tsuyuki 2006)

(Daigle-LeBlanc \& Kelloway 2002; Yang, Chen \& Wang 2012)

(Boh \& Wong 2013; Eze et al. 2013; Patriotta et al. 2013 )

(Hong \& Nguyen 2009; Ortega 2001) 
TABLE 1-A1 (Continues...): Identified knowledge transfer mechanisms.

\begin{tabular}{|c|c|}
\hline Number & Mechanism name \\
\hline 31 & Job shadowing \\
\hline 32 & Joint exercises \\
\hline 33 & $\begin{array}{l}\text { Knowledge broker/ } \\
\text { intermediary }\end{array}$ \\
\hline 34 & Knowledge repository \\
\hline 35 & $\begin{array}{l}\text { Knowledge sharing boards/ } \\
\text { bulletin boards }\end{array}$ \\
\hline 36 & Lessons learned logs \\
\hline 37 & Metaphors and analogies \\
\hline 38 & Mutual caring \\
\hline 39 & Networking \\
\hline 40 & $\begin{array}{l}\text { Newsgroups/online forum/ } \\
\text { web-based discussion }\end{array}$ \\
\hline 41 & Observation of practices \\
\hline 42 & $\begin{array}{l}\text { Project briefing/review } \\
\text { session }\end{array}$ \\
\hline 43 & Project report \\
\hline
\end{tabular}

\section{Mechanism description}

Transferring knowledge through working with another employee to help the person shadowing him or her to learn new aspects related to a specific job.

Transferring knowledge through the simulation of a certain (project) scenario and use the scenario to plan and execute a solution for the purpose of learning.

Transferring knowledge through a third party that offers intermediation and knowledge exchange services between two parties.

Transferring knowledge through a computerised system that systematically captures, organises and categorises knowledge. The repository can be searched and data can be quickly retrieved.

Transferring knowledge through the use of a computer-based bulletin board giving users access from remote locations to information contributed by one another and stored centrally.

Transferring knowledge through the learning in the process of doing a project. It can be seen as the knowledge gained as a result of trial and error or making mistakes.

Transferring knowledge by capturing underlying learnings from a project in a way that an individual relates real life to the metaphorical context.

Transferring knowledge through Mutual caring is whereby two people have comfortable conversations with each other, engage in and share insights on project issues and practice and develop self-confidence.

Transferring knowledge through a formal business or professional network and exchanging business or project information.

Transferring knowledge through a forum on a network or Internet for the discussion of a particular subject and the exchange of information about it on a centralised site.

Transferring knowledge through an informal act of observing watching or noticing a certain practice and learning from it.

Transferring knowledge through feedback on a project's progress and learning from it.

Transferring knowledge by reviewing the end project report on how the project performed against the version of the project initiation documentation that was used to authorise it.

$44 \quad$ Project review Transferring knowledge through the review of the project at project end and discussion the end project report.

45 Seminar Transferring knowledge through a form of academic instruction, bringing together small groups for recurring meetings, focussing bringing together small groups for recurr
each time on some particular subject.

46 Site visits/project visit Transferring knowledge through first-hand interaction with people working at the location to obtain feedback on the status of the project, to witness special activities and to discuss project issues.

47 Social activities/picnics Transferring knowledge through arranged social interactions between two or more individuals.

Transferring knowledge through informal social network ties between individuals and groups.

$48 \quad$ Social networks

$49 \quad$ Stage or phase review

$50 \quad$ Storytelling/narratives

Transferring knowledge through the review of a stage of the project focussing on all the different aspects of that specific stage.

Transferring knowledge through interpreting and sharing experiences in the form of a story.

$51 \quad$ Teaching

$52 \quad$ Team work session

53 Teleconferencing/videoconferencing

Transferring knowledge through the use of formal instruction where predefined knowledge and skills are transferred from one individual to another individual or to a group of individuals.

Transferring knowledge through a formal work session that has a specific purpose and goal to address a specific topic or issue in the project and can be attended by (active) participants and (passive) attendees.

Transferring knowledge through discussion between individuals and groups who are separated physically but linked by telecommunication devices or applications.

54 Telephone/video Conversation Transferring knowledge through discussion between two individuals who are separated physically but linked by a telecommunication device or application.

55 Templates and checklists Transferring knowledge through the use of standardised and pre-developed document templates and tick-off lists.

Transferring knowledge through sustained and formal instruction and practice and involves repetition to embed-specific knowledge or skills within a person of group of people.

$57 \quad$ Voice/audio mail

Transferring knowledge through a recorded message in an electronic system that is left by an incoming caller for subsequent playback and by the recipient.

$58 \quad$ Work package review

Transferring knowledge through a review session taking place at the end of a work package focussing on all the different aspects of that specific work package and its deliverables.

$59 \quad$ Wikis

\section{Citations}

(Jafari et al. 2011)

(Boh \& Wong 2013)

(Patriotta et al. 2013; Straus, Tetroe \& Graham 2009)

(Argote \& Ingram 2000; Gasik 2011; Patriotta et al. 2013;

Wickramasinghe \& Widyaratne 2012

(Conklin 2001; Christensen \& Bukh 2012)

(Disterer 2002; Jugdev \& Wishart 2014)

(Jasimuddin \& Zhang 2009; Jasimuddin et al. 2014)

(Jugdev \& Wishart 2014)

(Jasimuddin \& Zhang 2009; Petter et al. 2007)

(Patriotta et al. 2013; Wickramasinghe \& Widyaratne 2012)

(Hong \& Nguyen 2009; Jasimuddin \& Zhang 2009)

(Disterer 2002; Petter et al. 2007; Wickramasinghe \& Widyaratne 2012)

(Akram 2009; Bakker et al. 2011; d’Armagnac 2014)

(Disterer 2002; Jugdev \& Wishart 2014; Patriotta et al. 2013)

(Anne-Mette \& Ebba Holme 2011; Cantner, Joel \& Schmidt 2009; Gupta \& Polonsky 2014)

(Chilton \& Bloodgood 2010; Hong \& Nguyen 2009)

(Delen et al. 2013; Jasimuddin \& Zhang 2009)

(Jasimuddin et al. 2014)

(Disterer 2002)

(Jasimuddin \& Zhang 2009; Petter et al. 2007; Whyte et al. 2008; Wickramasinghe \& Widyaratne 2012

(Schulze, Brojerdi \& von Krogh 2014)

(Ajmal \& Koskinen 2008; Wickramasinghe \& Widyaratne 2012)

(Wickramasinghe \& Widyaratne 2012)

(Wickramasinghe \& Widyaratne 2012)

(Petter et al. 2007; Schulze et al. 2014)

(Hong \& Nguyen 2009; Jafari et al. 2011; Jasimuddin \& Zhang 2009; Nidhra et al. 2013; Wickramasinghe \& Widyaratne 2012)

(Cao \& Hoffman 2011; Conklin 2001; Jennex 2008)

(Ajmal \& Koskinen 2008; Disterer 2002)

(Wickramasinghe \& Widyaratne 2012) 